\title{
An Intragenic Deletion of the Factor IX Gene in a Family with Hemophilia B
}

\author{
Shi-Han Chen, Shinji Yoshitake, Philip F. Chance, Gordon L. Bray, \\ Arthur R. Thompson, C. Ronald Scott, and Kotoku Kurachi \\ Departments of Pediatrics, Biochemistry, and Medicine, University of Washington, Seattle, Washington 98195; \\ and Children's Orthopedic Hospital and Medical Center, Seattle, Washington 98105
}

\begin{abstract}
A family of seven patients severely afflicted with hemophilia B has been studied for their factor IX genes through the use of factor IX cDNA and genomic DNA probes. The patients had detectable ( $<10 \%$ of normal) factor IX antigen in urine and no detectable inhibitors in sera to factor IX protein. Based on the DNA hybridization analysis, these patients showed a partial intragenic deletion in their factor IX gene. The deletion included two exons (exons V and VI) coding for the amino acid sequence from number 85 to 195 of the factor IX protein. The deleted portion of the gene contained the entire factor IX activation peptide. The length of the deletion was estimated to be $10 \pm 0.3 \mathrm{ki}-$ lobase pairs. This specific gene has been named FIX ${ }^{\text {Sentle }}$. In this family both the deletion and a Taq 1 restriction fragment length polymorphism can be used as a useful marker for accurate detection of female carriers of the deficient factor IX gene.
\end{abstract}

\section{Introduction}

Hemophilia B is an X-linked disorder caused by the absence or dysfunction of the factor IX protein. The disorder occurs in about one in 30,000 newborn males. The factor IX gene has been cloned and sequenced (1-4), and the cDNA probes have been used for both genetic studies in families with hemophilia $B$ and to detect a restriction fragment length polymorphism (RFLP) ${ }^{1}$ that occurs in the general population $(5,6)$. Recently, two additional polymorphisms have been described with the restriction enzymes Xmn I, Hinf I, or Dde I (7). Using molecular hybridization techniques, the gene for factor IX has been localized at the distal long arm of the $X$ chromosome within the region designated as $\mathrm{Xq} 27$ to $\operatorname{Xqter}(5,8)$.

Using cloned DNA probes for factor IX, Gianelli et al. (9) have shown a gross gene deletion in four out of five patients with specific anti-factor IX antibodies. The fifth patient did not have DNA abnormalities detectable by Southern blot DNA analysis. More recently, a sixth patient was found to have at least a partial gene deletion $(10,11)$.

This report was published in abstract form in 1985. Clin. Res. 117A. Address reprint requests to Dr. Chen, Department of Pediatrics, RD20, University of Washington, Seattle, WA 98195. 1985.

Received for publication 4 March 1985 and in revised form 20 August

1. Abbreviations used in this paper: bp, base pair, $\mathrm{kb}$, kilobase pair, RFLP, restriction fragment length polymorphism.

J. Clin. Invest.

(c) The American Society for Clinical Investigation, Inc.

$0021-9738 / 85 / 12 / 2161 / 04 \quad \$ 1.00$

Volume 76, December 1985, 2161-2164
Here we report two hemophilia B patients in a family without factor IX inhibitors. We found that these patients had an abnormal factor IX gene with a partial deletion of $\sim 10$ kilobase pairs $(\mathrm{kb})$ in the middle portion of the corresponding normal gene.

\section{Methods}

The family in this study included seven males severely afflicted with hemophilia B (Fig. 1). Two of the seven patients had $\sim 0.1 \mathrm{U} / \mathrm{dl}$ of normal factor IX antigen (1 U/dl) in their sera, as determined by an immunoradiometric assay (12), and five of them had $<1 \%$ of normal factor IX procoagulant activity (13). Fresh blood was drawn from two of the boys (III-4, age 3, and III-8, age 7) for DNA study. Neither patient has been shown to exhibit inhibitory activity to factor IX, as determined by the method of Kasper (14), and each has received fresh frozen plasma and commercially concentrated factor IX in the past for bleeding episodes. Both are considered to be clinically well and functioning normally on a demand home transfusion program.

Between 100 to $400 \mu \mathrm{g}$ of DNA samples were prepared from 10 to $30 \mathrm{ml}$ of fresh heparinized blood according to the method described by Murray et al. (15). 10-15 $\mu \mathrm{g}$ of DNA was digested overnight with restriction enzymes according to the manufacturer's specifications (Bethesda Research Laboratories, Gaithersburg, MD). The digested DNA samples were then subjected to $0.8 \%$ agarnse gel electrophoresis in a Tris-phosphate-EDTA buffer (0.08 M Tris, $0.008 \mathrm{M}$ EDTA, adjusted to $\mathrm{pH} 8.2$ with $85 \%$ phosphoric acid). Gel electrophoresis was performed at room temperature for $20 \mathrm{~h}$ at $2.0 \mathrm{~V} / \mathrm{cm}$. After electrophoresis, the gel was immersed in the Tris-phosphate-EDTA buffer containing ethidium bromide $(0.5 \mu \mathrm{g} / \mathrm{ml})$ for $20 \mathrm{~min}$. Photographs of the gel were taken using a transmitted UV light box and Polaroid 667 film. The DNA fragments were then transferred to a nitrocellulose filter according to the method described by Southern (16). The filter was baked for $3 \mathrm{~h}$ at $75^{\circ} \mathrm{C}$, then prehybridized for $4-12 \mathrm{~h}$ at $42^{\circ} \mathrm{C}$ with $1 \%$ glycine in Stark's solution that contained $5 \times \operatorname{SSC}(0.3 \mathrm{M} \mathrm{NaCl}, 0.03 \mathrm{M} \mathrm{Na}$-citrate $), 1 \times$ Denhardt's solution, $0.3 \mathrm{mg} / \mathrm{ml}$ salmon sperm DNA, and $50 \%$ formamide. The hybridization was carried out with a radiolabeled probe $\left(\sim 5 \times 10^{6} \mathrm{cpm} /\right.$ filter) in a Stark's solution containing $10 \%$ dextran sulfate for $24-48 \mathrm{~h}$ at $42^{\circ} \mathrm{C}$. After hybridization, the filter was washed three times for $5 \mathrm{~min}$ each time in $2 \times$ SSC containing $0.1 \%$ sodium dodecyl sulfate (SDS) at room temperature and two times for $30 \mathrm{~min}$ each time at $65^{\circ} \mathrm{C}$ in 0.01 $\times$ SSC containing $0.1 \%$ SDS. After air drying, the filter was exposed to Kodak XAR film (Eastman Kodak, Rochester, NY) at $-70^{\circ} \mathrm{C}$ for $4-10$ d. Genomic DNA probes, as well as the cDNA probe (1), were labeled with $\alpha-\left[{ }^{32} \mathrm{P}\right]$ deoxynucleotides to $2-3 \times 10^{8} \mathrm{cpm} / \mu \mathrm{g}$ in a nick-translated reaction (17). The cDNA clone used as the probe contained the DNA sequence coding for entire signal peptide, mature protein, and part of the 3'-noncoding sequence (1). As shown in Fig. 5, genomic DNA probe 1 (333 base pairs [bp] in length) was located at $\sim 3.5 \mathrm{~kb}$ upstream of exon $\mathrm{V}$ in Intron $\mathrm{D}$; probe 2 (600 bp in length) was adjacent to probe 1 , also located in the intron $D$; probe 3 (1,311 bp in length) was located 3 ' downstream of exon VI in intron F. The genomic DNA probes were prepared from genomic DNA subclones in plasmids by digesting with Hind III (probe 1), Hind III and Hae III (probe 2), and Hind III and Eco Rl (probe 3), respectively (S. Yoshitake and K. Kurachi, unpublished data). 


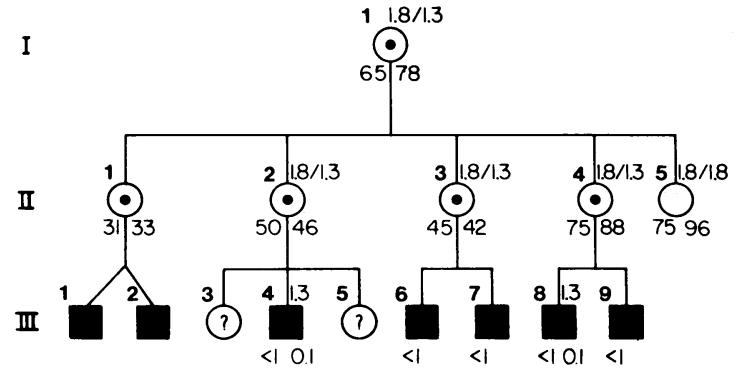

Figure 1. Pedigree of the factor IX deficient family. Taq 1 RFLP type is at the upper right of each subject's symbol: procoagulant activity expressed as percent of normal is at the lower left; antigen level expressed as $\mathrm{U} / \mathrm{dl}$ is at lower right. For normal controls, the antigen level is $1 \mathrm{U} / \mathrm{dl}$. $\odot$, carrier. $\square$, affected. $\odot$, normal.

\section{Results}

When purified DNA samples from normal individuals were digested with the restriction enzyme, Taq 1, and analyzed with the cDNA probe for RFLP, five invariable and two variable (or polymorphic) fragments were consistently observed. The invariable fragments consisted of pieces 5.0, 3.6, 2.7, 1.5, and 1.0 $\mathrm{kb}$ in length; and the two variable fragments were of 1.8 and 1.3 $\mathrm{kb}$ in length (Fig. $2 \mathrm{~A}$ ). Hemizygous males had either the 1.8or the 1.3-kb fragment, but not both. Females had either, or both fragments, as demonstrated in lanes $a-c$ of Fig. $2 A$. Of 148 chromosomes analyzed, the frequencies of the 1.8- and 1.3-
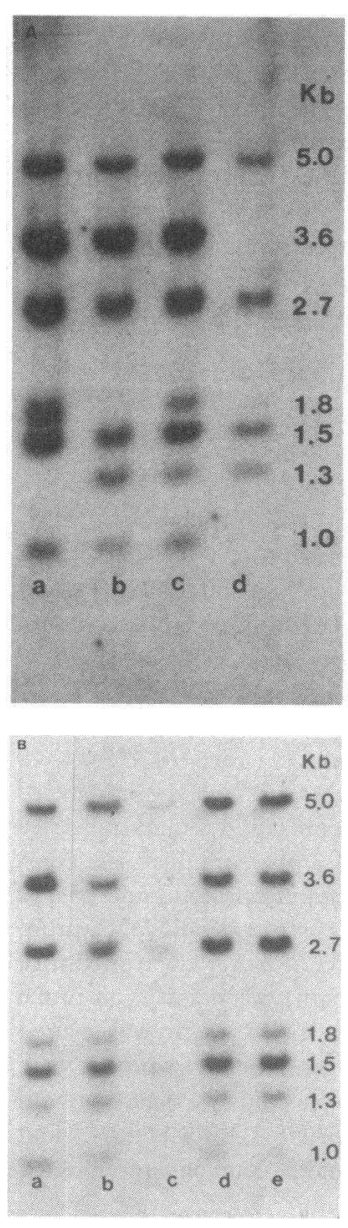

Figure 2. Southern blot analyses of DNAs digested with Taq 1 and hybridized with the factor IX cDNA probe from normal persons, patients with the factor IX deletion, and obligate heterozygotes. $(A)$ Three different RFLP types in normal females: lane $a$, 1.8 ; lane $b, 1.3$; and lane $c, 1.8 / 1.3$. Lane $d$ is one of the patients (III-4). $(B)$ The heterozygous types in a normal female (lane $a$ ) and three obligate heterozygotes (lane $b$ [II-2]; lane $d$ [II3], and lane $e$ [II-4], in Fig. 1). Lane $c$ is of the patient (III-4). The size of DNA fragments is expressed in kilobases.

$\mathrm{kb}$ fragments was $\sim 0.6$ and 0.4 , respectively, which agrees with previously published results (6).

Fig. $2 A$, lane $d$, shows the restriction fragment length pattern obtained from one of the affected males (III-4) whose DNA was digested with Taq 1. He retains the 5.0-, 2.7-, 1.5-, and 1.3-kb fragments, but he is missing the 3.6- and $1.0-\mathrm{kb}$ fragments. His cousin (III-8) has an identical pattern.

DNA prepared from three known obligate carriers from this family, II-2, II-3, and II-4, demonstrated that each of them has the 1.8- and 1.3-kb fragments (Fig. $2 B$, lanes $b, d$, and $e$ ). Since their male offsprings with hemophilia demonstrate the $1.3-\mathrm{kb}$ fragment, this 1.3-kb RFLP represents a marker for the hemophilia $\mathrm{B}$ gene in this pedigree. It is also apparent that the relative intensities of the 3.6- and 1.0-kb fragments from the obligate carriers are weaker than those observed from a normal female control (Fig. $2 B$, lane $a$ ). Levels of factor IX procoagulant activity, factor IX antigen levels, and the RFLP phenotype of each member of this family are indicated within the pedigree in Fig. 1.

Autoradiographs of Southern blots of normal and patient genomic DNA samples digested with Eco R1 and Bam $\mathrm{H} 1$ and hybridized to the cDNA probe are shown in Fig. 3. The Eco R1 digestion of DNA samples of normal individuals generated five fragments: $13,6.8,5.5,4.8$, and $4.6 \mathrm{~kb}$ in length, as estimated by agarose gel electrophoresis. These are illustrated in lanes $a$, $c$, and $d$ in Fig. $3 A$. In genomic DNAs obtained from the patients under study (III-4 or III-8), the 6.8 - and $4.6-\mathrm{kb}$ fragments are absent (lane $b$ in Figure $3 A$ ). Digestion with Bam $\mathrm{H} 1$ followed by hybridization with the cDNA probe generates only a single broad band of $\sim 22-27 \mathrm{~kb}$ in length in the control (Fig. $3 \mathrm{~B}$, lane $a$ ), while two bands of 24.5 and $17 \mathrm{~kb}$ in length are seen in the patient (Fig. $3 B$, lane $b$ ).
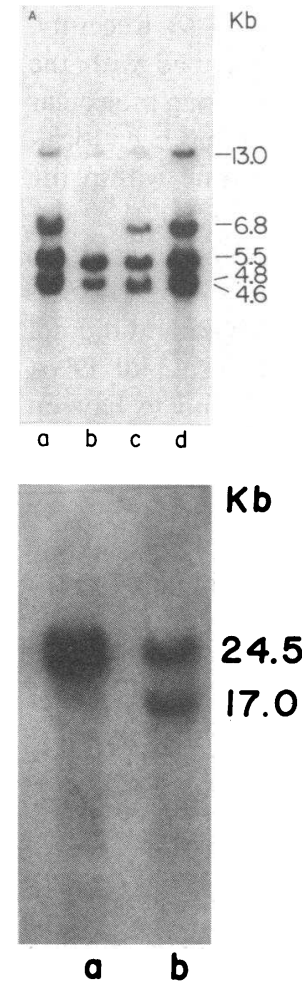

Figure 3. Southern blot analyses of normal and patient DNA digested with Eco $\mathrm{R} 1$ and Bam $\mathrm{H} 1$ and hybridized with the cDNA probe. $(A)$ Eco R1 digestions of DNA hybridized with factor IX cDNA. Lanes $a, c$, and $d$ are from normal persons; $b$ is from the patient. ( $B$ ) Bam H1 digestions: lane $a$ is from a normal individual and lane $b$ is from the patient. 


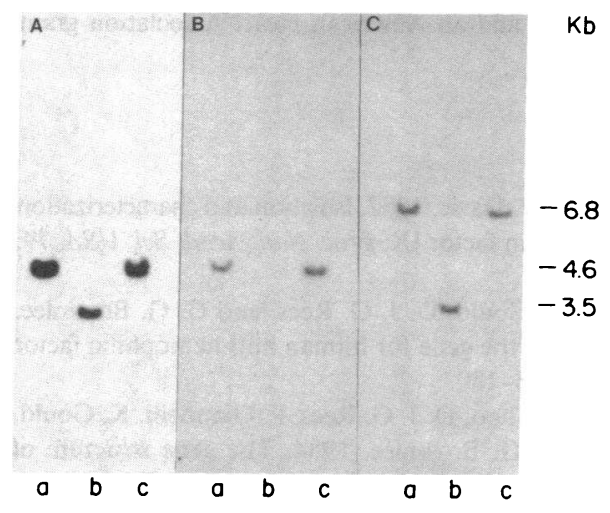

Figure 4. Southern blot analyses of normal and patient DNA digested with Eco R1 and hybridized with the prepared genomic DNA probes. $(A)$ hybridized with the probe $1 ;(B)$ hybridized with the probe 2 ; and $(C)$ hybridized with probe 3 . In each blot, lanes $a$ and $c$ are DNA samples from normals and lane $b$ is DNA sample from a patient (III4).

To further define the deletion sites in this abnormal factor IX gene, three genomic DNA probes were used (Fig. 4). When probe 1 was hybridized to Eco R1-digested DNA, only a 3.5-kb fragment was observed in the DNA sample from the patient, while the normal control contained a 4.6-kb fragment (Fig. 4 $A$ ). When probe 2 was used, no hybridization to any DNA fragment could be detected in the DNA from the patient, while a 4.6-kb fragment was present in normal control (Fig. $4 \mathrm{~B}$ ). When probe 3 was used on the same Eco R1 digestions, the patient had a 3.5-kb fragment instead of a 6.8-kb fragment observed in control samples (Fig. $4 C$ ). These results indicate that the $5^{\prime}$ site of the deletion occurs between exons IV and V. Specifically, the 5 deletion is within the site that corresponds to the genomic probe 1 (333 bp in length).

\section{Discussion}

It was clear from the use of the cDNA probe for factor IX that the males with hemophilia $B$ have an intragenic deletion within the factor IX gene. We have named this specific defective gene FIX ${ }^{\text {Seattle }}$. The site of this deletion is shown in Fig. 5. The deletion in the gene resulted in the loss of exon V and exon VI. The extent of the deletion on either side of these exons was not able to be determined by the cDNA probe alone. Southern blot analyses employing the three genomic probes further delineated the sites and extent of the deletion.

Probes 1 and 2 are genomic DNA probes of $\sim 0.3$ and 0.6 $\mathrm{kb}$ in length and are adjacent to and contiguous with each other. DNA prepared from normal individuals and the patient hybridized with probe 1 , while probe 2 hybridized with DNA from normals but did not hybridize with DNA from the patient. This indicates that the deletion occurs within the region of probe 1 . It is possible, however, that the deletion may start close to the $5^{\prime}$ region of probe 2 at or near the immediate vicinity of its contact to probe 1 . This possibility has not been excluded. Since both probe 1 and probe 3 hybridized to the same 3.5-kb fragment, this fragment represents the remaining DNA segment that would normally be generated from an Eco R1 digest of normal DNA and would include the 4.6-, 2.1-, and 6.8-kb sections. The difference between these fragments and the remaining $3.5-\mathrm{kb}$ segment represents the size of the deletion, $\sim 10 \mathrm{~kb}$. Since probe 1 is the approximate limit of resolution of the detection system employed in this study, the size of the intragenic deletion is estimated to be $10.0 \pm 0.3 \mathrm{~kb}$. The precise size and delineation of the deletion sites will be determined by sequencing the DNA fragment containing the deletion junction sites. At the level of translation, the deletion would include the coding region for the amino acid sequences 85 through 195 of the factor IX protein. This region includes the activation cleavage sites and the entire activation peptide (residues 146-180).

A
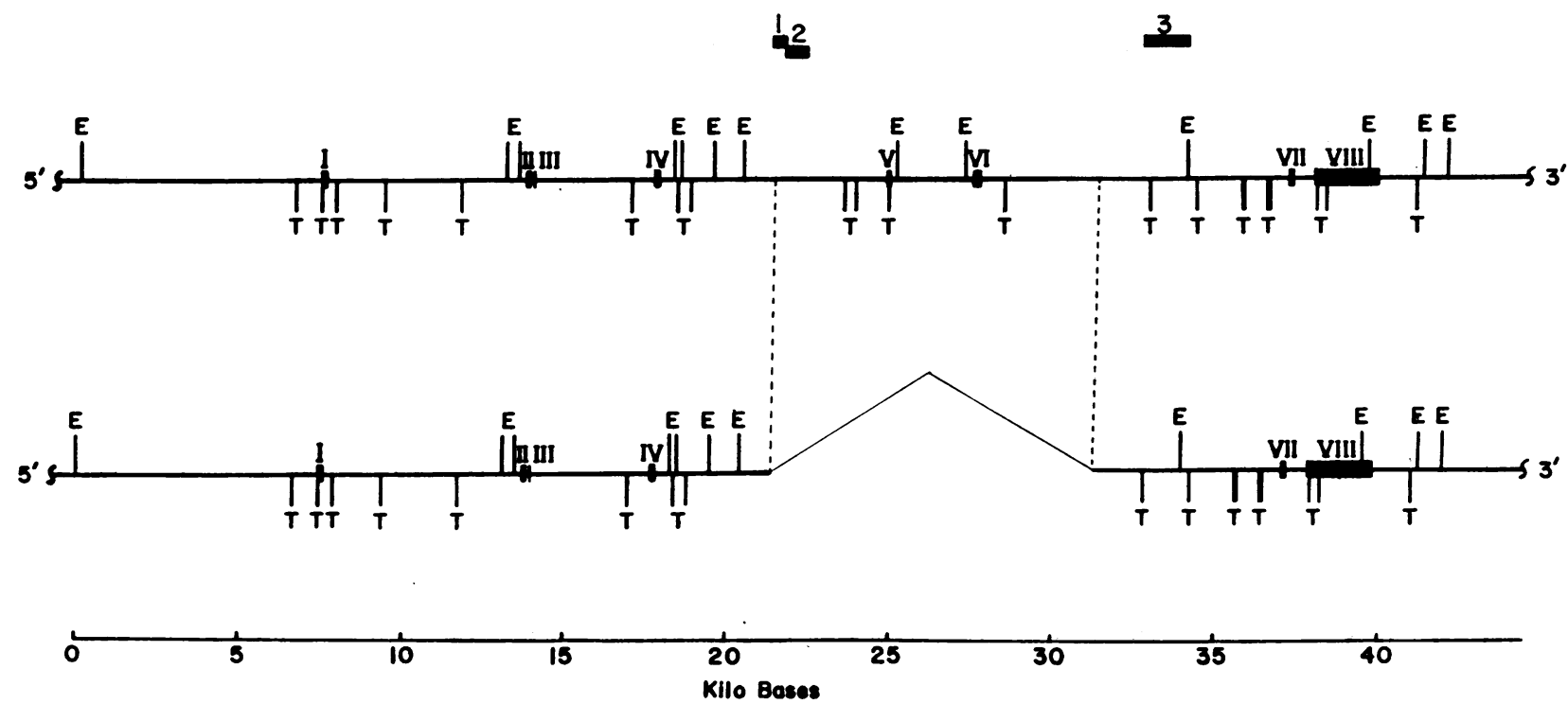

Figure 5. The site of the deletion in the abnormal factor IX gene. $A$ shows the normal factor IX gene with Eco RI $(E)$ and Taq $1(T)$ sites. Exons are shown as solid regions labeled with roman numerals (I to VIII). The sites of the genomic probes employed are depicted as solid bars with arabic numbers at the top (1 to 3 ). $B$ shows the factor IX gene with the partial deletion delineated in the patients. The deleted segment $(\sim 10 \mathrm{~kb})$ corresponding to the normal gene is shown between the dotted lines. The organization of the normal gene in $A$ is according to Yoshitake et al. (4). The restriction sites in the $5^{\prime}$ region of the gene are not complete in this figure. 
Gianelli et al. (9) have previously reported patients from the United Kingdom with deletions involving all or part of the factor IX gene. These patients were selected for DNA analysis because they were known to have detectable antibodies against the factor IX protein. Of the five patients studied, four were shown to have detectable gene deletions involving all or part of the factor IX gene. Whether any of these patients has the same deletion detailed in this report is not clear. They did not detect any observable deletions in 20 patients who did not have antibodies to the factor IX protein. They suggested that antibodies were produced in these patients because of $(a)$ the absence of an immunologically recognizable factor IX, $(b)$ breakdown of tolerance as a result of exposure to cross-reacting antigens, or $(c)$ the existence of factor IX allotypes. They favored the first suggestion as a reasonable hypothesis, since the use of factor IX protein in the treatment of hemophilia B would present a protein to the host that might not be recognized as "self" by the host immunological system. Our patients do not have detectable inhibitory antibodies to factor IX in their sera.

A residual question in this family is whether or not the defective gene is transcribed and translated. Bray and Thompson (18) have preliminary information that would indirectly indicate the deleted factor IX gene does form mRNA and translate a protein fragment. From urinary sediments they were able to demonstrate the presence of a partial factor IX protein $(<10 \%$ of expected) by using a polyclonal antibody and assaying by an immunoradiometric method. The presence of this protein fragment may confer enough immunologic memory to prevent the formation of antibodies to exogenous factor IX protein.

Use of the cDNA probe in this family was most informative for genetic counselling of female relatives of the patients. In all $\mathrm{X}$-linked diseases in which the gene product is used for heterozygote detection, a reliability of $>80 \%$ is rarely achieved. In this family, two females (II-4 and II-5) had factor IX activities and antigen levels that were compatible with those within the range of normal persons. The woman II-4, however, was unequivocally an obligate carrier for hemophilia $B$ because she had given birth to two males with factor IX deficiency. Her sister (II-5), however, has not yet reproduced and her carrier status remained to be determined in spite of having activity levels and antigen levels within the normal range. This woman, however, is now classified as a noncarrier on the basis of the normal autoradiographic intensity of the 3.6- and 1.0-kb Taq 1 fragments of her DNA that hybridized with the cDNA probe and the fact she did not inherit the 1.3-kb polymorphic fragment that is known to be associated with the gene for factor IX deficiency in this family. In this family, therefore, the cDNA probe was used successfully for carrier detection and genetic counselling. It could also be used for prenatal diagnosis under appropriate conditions.

\section{Acknowledgments}

We thank Dr. E. W. Davie for his valuable discussion and encouragement during the study and Dr. Beverly White for her participation in the preliminary work at The Children's Orthopedic Hospital and Medical Center, Seattle WA. The authors appreciate the persistence of Ms. Marti Berry in preparation of the manuscript.

This work was supported in part by a grant from the Maternal and Child Health Service, project 913; a National Institutes of Health grant,
HL 31511 to Dr. Kurachi; and an American Heart Association grant 84-1030 to Dr. Thompson.

\section{References}

1. Kurachi, K., and E. W. Davie. 1982. Isolation and characterization of a cDNA coding for human factor IX. Proc. Natl. Acad. Sci. USA. 79: 6461-6464.

2. Choo, K. H., K. G. Gould, D. J. G. Recs, and G. G. Brownlee. 1982. Molecular cloning of the gene for human anti-hemophilic factor IX. Nature (Lond.). 299:178-180.

3. Anson, D. S., K. H. Choo, D. J. G. Rees, F. Giannelli, K. Gould, J. A. Huddleston, and G. G. Brownlee. 1984. The gene structure of human anti-haemophilic factor. EMBO (Eur. Mol. Biol. Organ.) J. 3: 1053-1060.

4. Yoshitake, S., B. G. Schach, D. C. Foster, E. W. Davie, and K. Kurachi. 1985. Complete nucleotide sequence of the gene for human factor IX (anti-hemophilic factor B). Biochemistry. 24:3736-3750.

5. Camerino, G., G. H. Grzeschik, M. Jaye, H. De La Salle, P. Tolstoshev, J. P. Lecocq, R. Heilig, and J. L. Mandel. 1984. Regional localization on the human $\mathrm{X}$ chromosome and polymorphism of coagulation factor IX gene (hemophilia B locus). Proc. Natl. Acad. Sci. USA. $81: 498-502$.

6. Gianelli, F., K. H. Choo, P. R. Winship, C. R. Rizza, D. S. Anson, D. J. G. Rees, N. Ferrari, and G. G. Brownlee. 1984. Characterization and use of an intragenic polymorphic marker for detection of carriers of hemophilia B (factor IX deficiency). Lancet. I:239-241.

7. Winship, P. R., D. S. Anson, C. R. Rizza, and G. G. Brownlee. 1984. Carrier deletion in hemophilia $B$ using two further intragenic restriction fragment length polymorphisms. Nucl. Acids Res. 12:8861-8872.

8. Chance, P. F., K. A. Dyer, K. Kurachi, S. Yoshitake, H. H. Ropers, P. Wieaker, and S. M. Gartler. 1983. Regional localization of the human factor IX gene by molecular hybridization. Hum. Genet. 65:207-208.

9. Gianelli, K., K. H. Choo, D. J. G. Rees, Y. Boyd, C. R. Rizza, and G. G. Brownlee. 1983. Gene deletions in patients with haemophilia $B$ and anti-factor IX antibodies. Nature (Lond.). 303:181-182.

10. Peake, I. R., B. L. Furlong, and A. L. Bloom. 1984. Carrier detection by direct gene analysis in a family with haemophilia B (factor IX deficiency). Lancet. i:242-243.

11. Peake, I. R., B. L. Furlong, A. L. Bloom, and G. G. Brownlee. 1984. Carrier detection by gene analysis in a family with Christmas disease (factor IX deficiency). Br. J. Haemotol. 58:170. (Abstr.)

12. Thompson, A. R. 1984. Factor IX and prothrombin in amniotic fluid and fetal plasma: constraints on prenatal diagnosis of hemophilia B and evidence of proteolysis. Blood. 64:867-874.

13. Proctor, R. R., and S. I. Rapaport. 1961. The partial thromboplastin time with kaolin. A simple screening test for first stage plasma clotting deficiencies. Am. J. Clin. Pathol. 36:212-219.

14. Kasper, C. K. 1984. Measurement of factor VIII inhibitors. In Factor VIII Inhibitors. Leon W. Hoyer, editor. Alan R. Liss, Inc., New York. 87-98.

15. Murray, J. C., C. M. Demopulos, R. M. Lawn, and A. G. Motulsky. 1983. Molecular genetics of human serum albumin: restriction enzyme fragment length polymorphism and analbuminemia. Proc. Natl. Acad. Sci. USA. 80:5951-5955.

16. Southern, E. M. 1975. Detection of specific sequences among DNA fragments separated by gel electrophoresis. J. Mol. Biol. 98:503517.

17. Kelly, R. B., N. R. Cozzarelli, M. P. Deutscher, I. R. Leman, and A. Kornberg. 1970. Enzymatic synthesis of deoxyribonucleic acid XXXII. Replication of duplex deoxyribonucleic acid by polymerase at a single strand break. J. Biol. Chem. 245:39-45.

18. Bray, G. L., and A. R. Thompson. 1985. Partial factor IX antigen (IX:Ag) in urines from normal subjects and patients with hemophilia B due to partial gene deletion. Clin. Res. 33:544A. (Abstr.) 